\title{
Gap Analysis of Farmers' Capacity Building by Public and Private Agriculture Extension Sectors in Central Plain Valley of Khyber Pakhtunkhwa, Pakistan
}

\section{Shahzad Malik* and Ayesha Khan}

Department of Agricultural Extension Education and Communication, Faculty of Rural Social Sciences, The University of Agriculture, Peshawar, Khyber Pakhtunkhwa, Pakistan.

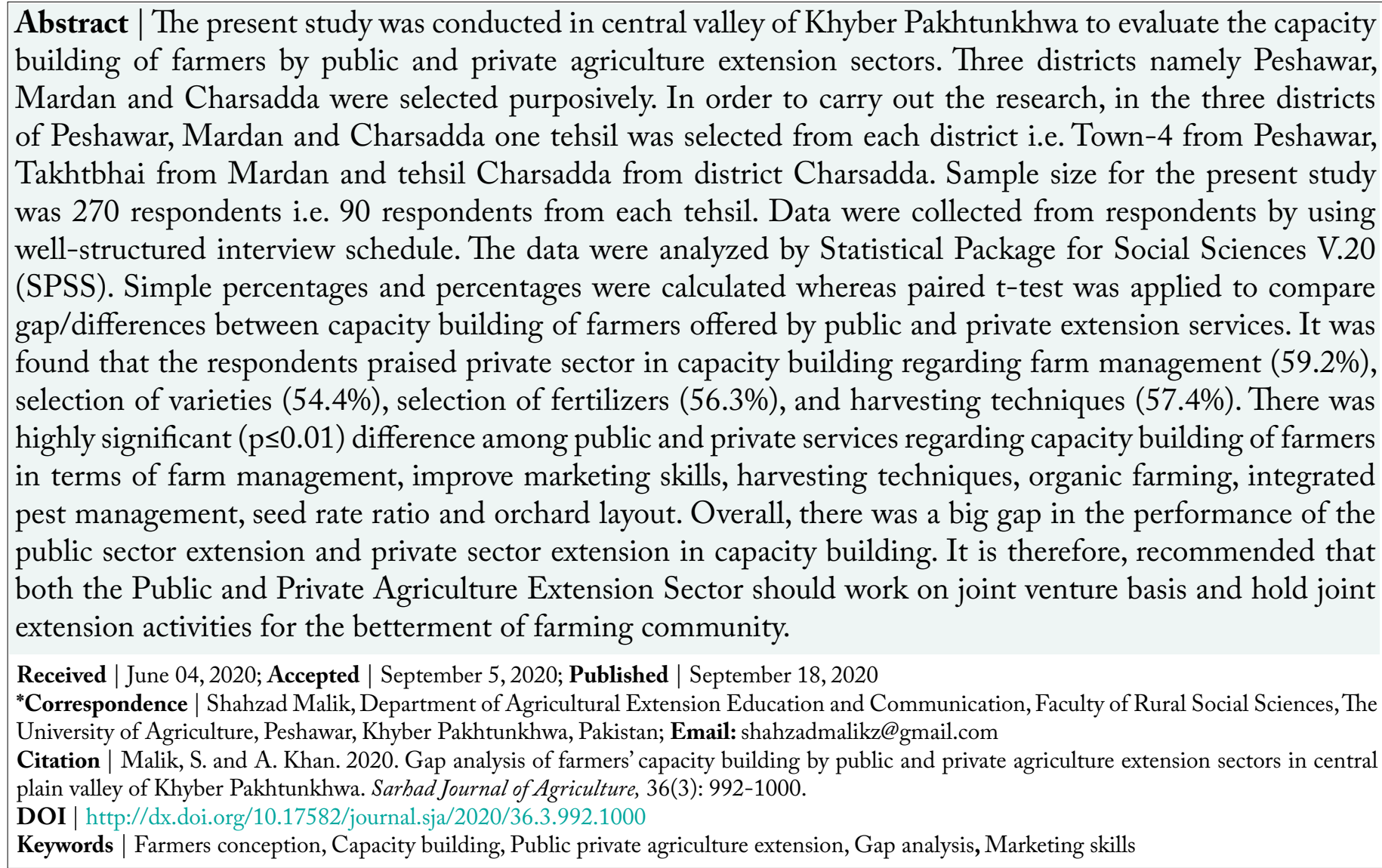

\section{Introduction}

A griculture is important sectors of a country's economy. History of economic development of the developed nations or those who have embarked on the path of development, it is "agriculture" which has made the foundation of the prosperity of other sectors and economy as well (Pretty, 2008). Therefore, agriculture is considered backbone of economies of many nations including Pakistan. This is a fact that agriculture has contributed significantly and brought precious amount of foreign exchange to the national exchequer. Agriculture sector in Pakistan performs a vital role in economy. It is largest sector which 
contributes $18.9 \%$ of GDP and captivating $42.3 \%$ employment of entire labor force of the country. It also a vital source of foreign exchange earnings and stimulates growth in other sectors (GoP, 2018).

Agricultural extension can play a crucial role in disseminating technological packages that are environment friendly, conserving natural resource base and also enhancing quality production. However, sustainable agriculture is not only the domain of agriculture extension and research, besides other considerations like appropriate policy, environment, farmers' awareness, knowledge and active role of other beneficiaries of agriculture can significantly influence sustainability (Kumbhar et al., 2012). In Khyber Pakhtunkhwa (KP) Pakistan, majority of farmers are subsistence producers with holding sizes of less than one hectare, this group of farmers have poor resource, with minimal access to inputs, credit and guidance facility. This group of farmers lacks the power and organizational capacity to employ pressure on the research, extension and other public establishment to meet their needs. In addition, farmer's community access to all information is often weak because in most cases they are found less knowledgeable and uneducated (Ahmad et al., 2007).

The public sector and its affiliated organizations such as Research Department, Outreach, Plant Protection and Horticulture are the major facilitators in providing support and feedback to agricultural extension services in order to improve standard of the farming community (World Bank, 2010). Besides, various private enterprises are also extending their services which include, but not limited seed distributing agents, pesticide dealers, fertilizer dealers and other crop management equipment dealers etc. The mixture of public and private extension activities which survives in most countries and their affiliations with adjacent communities, organizations and institutions comprise an extension system (Heemskerk and Davis, 2012).

Extension professionals working frequently provide numerous services like capacity building, trainings in various sectors, income generation activities, marketing skills and education through extension teaching methods. In order to produce benefits in accordance with a positive objective such as increased production, better use of the inputs, access to an exact type and quality of output for domestic and export, extension agents must provide platform to clientele. It is evident that various research studies have been conducted on the said topic but comprehensive apprehensions of the farmers could not be identified. It is alarming to take steps to eradicate the weaknesses and threats should be changed into opportunities in system (Ali et al., 2009). It is therefore need of the hour, that agriculture extension services are designed in new prototype with the light of rural socioeconomic characteristics of growers, accessible qualified and skilled human resources (Khushk and Memon, 2004; Khan, 2006). Therefore, the present study was designed with the objective to identify the gap and differences in the capacity building of the farming community from farmers perspective in various agriculture practices.

\section{Materials and Methods}

\section{Universe of the study}

The present study was carried out in the central plain valley zone of Khyber Pakhtunkhwa, Pakistan because public and private extension services are being provided to the farmers since long with full zeal as these areas have canal irrigated lands and great potential to produce multiple crops, that's why both sectors focus to uplift agricultural activities and improve local and national economy respectively.

\section{Research design}

Research design of the proposed study is descriptive survey because, this type of design is considered most appropriate for obtaining people's perception on socio-economic facts. This design describes the characteristics or behavior of a particular population in a systematic and accurate fashion. By descriptive survey researcher gained a better understanding of aspects of the study and the nature of existing condition in a situation.

\section{Multistage sampling technique}

For selection of respondents' multistage sampling technique was used. A sample is called multistage when sampling is passed out in different stages, using smaller and smaller units at each phase (Table 1).

From four agro ecological zones central plain valley (agro-ecological zone-C) was selected purposively because this region is highly fertile and rich agriculture zone. Public and private extension services agents mostly focus on this zone. In second stage from the selected agro-ecological zone i.e. central plain valley, 
three districts were purposively selected viz. Peshawar, Mardan and Charsadda. These districts were selected because in the central plain valley, these districts have a predominant importance regarding agricultural activities and production of various crops. In the third stage from the selected districts one tehsil was purposively selected i.e. town-4 was selected from Peshawar district whereas tehsil Takht Bhai and tehsil Charsadda were selected from district Mardan and Charsadda respectively.

\section{Table 1: Stage I: Selection of agro-ecological zone.}

\begin{tabular}{|c|c|c|c|}
\hline S. No. & Zone & Description & Districts \\
\hline 1 & A & $\begin{array}{l}\text { Higher northern } \\
\text { mountains }\end{array}$ & $\begin{array}{l}\text { northern mountains Buner, } \\
\text { Shangla, Dir/Lower and } \\
\text { Upper, Swat and Chitral }\end{array}$ \\
\hline 2 & B & $\begin{array}{l}\text { Sub humid eastern } \\
\text { mountains and wet } \\
\text { mountains }\end{array}$ & $\begin{array}{l}\text { Haripur, Batagram, } \\
\text { Mansehra, Abbottabad, } \\
\text { Kohistan, Torghar }\end{array}$ \\
\hline 3 & $\mathrm{C}$ & Central valley plain & $\begin{array}{l}\text { Peshawar, Mardan, } \\
\text { Charsadda, Nowshera, } \\
\text { Swabi, Kohat, Hangu }\end{array}$ \\
\hline 4 & $\mathrm{D}$ & $\begin{array}{l}\text { Piedmont plain, } \\
\text { Suleiman piedmont }\end{array}$ & $\begin{array}{l}\text { Bannu, Karak, Lakki } \\
\text { Marwat, Tank, D.I. Khan }\end{array}$ \\
\hline
\end{tabular}

Source: (Ahmad, 2012).

\section{Selection of sample size/respondents}

The sample size was determined on the basis of guesses variability i.e. 50\% for maximum sample size as suggested by Kasely and Kumar (1989). Therefore, the number of farmers included in the study (participants) was determined using formula for unknown population.

$$
n=Z^{2} \frac{V^{2}}{D^{2}}
$$

The aforesaid terms can be explained in such a way $\mathrm{n}=$ Total size of the sample; $\mathrm{D}=$ Estimate acceptable margin (6\%); $Z=$ Error of the confidence level limit or normal variation (95\%) and constant for this value is $1.96 ; \mathrm{V}=50 \%$ is because similar studies were difficult to find and taking the assumption that $50 \%$ of the farmers had taken the services both from private and public extension sector; $\mathrm{n}=(1.96)^{2} \mathrm{x}(50)^{2} /(6)^{2}=267$ almost 270 .

Farmers from all the three selected districts were divided equally as per calculation i.e. $(270 / 3=90)$. Ninety farmers were selected from aforementioned districts of the central plain valley zone Table 2 .
Table 2: Selection of respondents from each district.

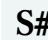

1.

2.

3.

Total

\section{Sample size}

90

90

90
Furthermore, for selection of farmers, convenience sampling technique was utilized. Data were collected only from those who fulfilled the inclusion criteria.

\section{Inclusion and exclusion criteria}

All the farmers who got benefited from both public and private extension services were considered as respondents of the present study. Similarly, a criterion was also set that all the respondents having farming experience more than 5 years were selected, so that better in-depth investigations may be made.

\section{Data collection instrument}

Keeping in view the objective of the study wellstructured interview schedule was prepared which is comprised of open ended, close ended and partially open-ended questions. Though the interview schedule was in English language, but it was translated into local language in order to accumulate firsthand information. Five point Likert Scale weightage of 5 was used, which usually gives us idea regarding ascending order, usually written as $1=$ very low, 2 low, 3 medium, 4 high and 5 very high (Likert, 1932; Ajayi and Gunn, 2009).

\section{Data collection}

Both primary and secondary data were collected for the present study. The secondary data were collected from various published and unpublished sources. Primary data were collected from the sampled respondents.

\section{Data analysis}

The collected data were entered into the Statistical Package for Social Sciences (SPSS) version (20). Simple percentages and frequencies were calculated. Moreover, to test the mean differences among the public and private extension services paired t-test was utilized, paired t-test examines the mean of individual differences of paired measurements (Park, 2009) as used by (Zaman et al., 2016; Sathish, 2015; Ali et al., 2013; Khan, 2015; Iqbal and Nawab, 2013; Kamal, 2013; Ayinde et al., 2004) in their research study. 
Whereas:

of marketing skill by public extension sector.

$$
d=\frac{\Sigma \mathrm{d}}{n}
$$

is the mean of $d$-values,

where;

$\mathrm{d}=$ difference between observations public and private extension services

$$
\mathrm{Sd}=\frac{\sqrt{\sum(d-d)^{2}}}{\mathrm{n}-1}
$$

$\mathrm{n}=$ number of pairs.

\section{Results and Discussion}

\section{Capacity building by extension services}

Capacity building in extension is considered a series of learning steps which comprises training and other modules for the augmentation of potential capabilities and improvement of skills of individuals involved in farming activities. It includes training and all other forms of learning that improve information, knowledge and competencies (skills) of individuals (Gordon and Chadwick, 2007). Information distribution, training, facilitation and monitoring are the main tools for development of capacities. Training is often used as the main capacity building method for agricultural extension in developing countries. Capacity building helps in building linkages between farmers and stakeholders involved in helping farmers Table 3.

Results in Table 3 revealed that about $37.1 \%$ respondents reported capacity building in farm management by public extension staff, while $56 \%$ respondents denied capacity building for farm management by public sector. Similarly, 59.2\% respondents agreed that private extension services build their capacity regarding farm management. Agriculture extension services also provide information to facilitate farmers in marketing knowledge and try to build their capacity accordingly. Of the total sample, 58.5\% respondents stated their improvement of marketing skills by public extension staff, while for the public extension sector only $33.3 \%$ of the total respondents' capacity building in marketing skills. Our results are in contrast with that of (Lodhi et al., 2006) who reported that only $28 \%$ respondents reported capacity building
Most of the farmers in our country use old varieties and are not aware of modern practices in farming and high yielding varieties. Extension services are involved in capacity building of farmers providing information regarding innovative agricultural practices and selection of high yielding varieties. Results in Table 3 depicts that about $45.9 \%$ respondents confirmed capacity building by public extension services in proper selection of varieties, while $44.8 \%$ respondents negated capacity building by public sector. Similarly, $54.4 \%$ respondents had capacity building by private extension services, while $38.2 \%$ respondents did not receive capacity building regarding selection of varieties by private extension services. Our results are in close agreement with that of Singh and Narain (2008) who reported that private extension services provided information to farmers and build their capacities about new seed varieties.

Proper amount of fertilizer plays an important role to enhance crop yield. During informal discussion with the respondents it was found that the farmers in the study area frequently apply high amount of nitrogen with small quantity of phosphorous which might have adverse effect on soil fertility resulting low production. It should be according to soil condition and its $\mathrm{pH}$ value, to overcome this ignorance of the farming community. About $47.8 \%$ respondents confirmed capacity building regarding the proper selection of fertilizer by public extension staff, while $44.1 \%$ respondents negated the capacity building about proper selection of fertilizer by public extension staff. Likewise, $56.3 \%$ respondents reported that private sector build their capacity in proper selection of fertilizer as against $34.5 \%$ respondents in the study area. Harvesting is the last practice after completion of crop growth. It needs proper technique to educate the farmers to use advance methods for crop harvesting and to eradicate use of old practices. The data showed that $40 \%$ respondents confirmed the capacity building in harvesting techniques by public extension staff, while $53.3 \%$ respondents denied the capacity building of farmers in the said technique by public extension staff. Likewise, 57.4\% respondents agreed the capacity building of farmers in harvesting by private extension services, while $36.6 \%$ respondents had no capacity building in harvesting techniques by private extension services. 
Table 3: Farmers perception regarding capacity building in various fields.

Capacity building

\begin{tabular}{lc} 
& Strongly disagree \\
Farm management & $52(19.3)$ \\
Improve marketing skills & $40(14.8)$ \\
Selection of varieties & $38(14.1)$ \\
Selection of fertilizer & $50(18.5)$ \\
Harvesting techniques & $61(22.6)$ \\
Organic farming & $40(14.8)$ \\
food processing & $50(18.5)$ \\
Integrated water management & $57(21.1)$ \\
Integrated pest management (IPM) & $36(13.3)$ \\
Seed rate ratio & $55(20.4)$ \\
Time of sowing & $52(19.3)$ \\
Orchard layout & $37(13.7)$ \\
Private sector farmers' perception regarding in capacity building \\
Farm management & $40(14.8)$ \\
Improve marketing skills & $53(19.6)$ \\
Selection of varieties & $35(13.0)$ \\
Selection of fertilizer & $52(19.3)$ \\
Harvesting techniques & $33(12.2)$ \\
Organic farming & $61(22.6)$ \\
food processing & $42(15.6)$ \\
Integrated water management & $76(28.1)$ \\
Integrated pest management (IPM) & $49(18.1)$ \\
Seed rate ratio & $40(14.8)$ \\
Time of sowing & $51(18.9)$ \\
Orchard layout & $50(18.5)$ \\
\hline
\end{tabular}

Source: Field Data, 2017-18; (figures in parenthesis are percentages).

Organic farming is used for crops and livestock production in which minimum use of pesticide application is encouraged to avoid health hazards due to toxicity of chemicals used in pesticides. Similarly, less application of fertilizers and more use of organic products like FYM etc. The data showed that 57.8\% of the respondents had received capacity building in organic farming by public extension staff where for the private sector only $32.9 \%$ respondents reported that their capacity was built in organic farming by private extension sector. Respondents of the study area also revealed during informal discussion that our crops profit sometime even not cover the cost of production due to fluctuation in the market, this is known as glut season in technical terminology. To avoid this type of scenario public and private extension sectors arrange capacity building sessions for the end-users to cope with situation like this and techniques are being taught to the end users like the food processing and value addition so that better profit can be obtained from the crop. The overall data revealed that $52.9 \%$ respondents confirmed the capacity building in food processing by public extension staff whereas for the private sector only $38.1 \%$ of the total respondents reported the capacity building in food processing. Ours results are also been supported by the results of Umeh et al. (2018) who reported that public extension agents used field demonstrations to train farmers in food processing techniques.

Water management is very important for any crop. Most of the farmers have medium knowledge regarding proper use of water for higher crop yield, while some farmers have no knowledge in this regard. 
Extension services provide capacity building sessions to farmers about water management practices and perception of farmers is explained in Table 4. A total of $58.5 \%$ respondents mentioned the capacity building in water management by public extension staff, while $33.7 \%$ respondents negated the statement. Likewise, $38.1 \%$ respondents reported the capacity building in water management by private extension services, while $54.4 \%$ respondents were not pleased with capacity building sessions in water management by private extension services. Ali et al. (2011a) suggested that private sector should provide information to farmers about water management.

Integrated pest management (IPM) is a method to control crop diseases mostly with biological control instead of chemical application. Its process needs proper knowledge about its implementation; however, most farmers do not know about how to deal with this environment friendly activity. Chemical application is not the sole solution to control diseases and pest attack to improve crop yield. The data in Table 3 showed that $64.8 \%$ respondents confirmed their capacity building in integrated pest management by public extension staff, while $27.4 \%$ respondents denied the statement. Similarly, 32.6\% respondents reported that we get benefitted from the capacity building session in IPM by private extension services, while $58.8 \%$ respondents disagreed. The data showed that public extension services mostly provided the capacity building in integrated pest management, while on the other hand private sector mostly focus on chemical control against pest, insect, and other viral or fungal diseases. These results are in full contrast with that of Ali et al. (2011a) who stated that $90 \%$ of the farmers got IPM knowledge from private extension workers. Similarly, utilization of proper seed rate is a common practice in agriculture which needs sufficient knowledge for increased crop production. Data revealed that $41.5 \%$ respondents reported in favor of capacity building in seed rate ratio by public extension staff, while $51.5 \%$ respondents denied the statement. Similarly, 57.8\% respondents confirmed the capacity building in seed rate ratio by private extension services, while $34.4 \%$ respondents had no capacity building in seed rate ratio by private extension services. Bahalkani (2013) also reported that farmers adopted the recommended practices of seed rate ratios and insects control measures during capacity building sessions.

Accurate time of sowing may increase the productivity of any crop. Most of the farmers' use their parental timetable for sowing crop, while change in climate has done abrupt changes in time of sowing of different crops. Cabbage, wheat, cucumber and other vegetable and cereal crops timing has been changed in the last few years. Some farmer uses this technique to capture early market for maximum profit. The data of time of sowing in Table 3 showed that $40.7 \%$ respondent's capacity has been built by public extension staff, while $52.6 \%$ respondents told that no such type of sessions had been arranged by public sector. In addition, 53\% respondents reported their capacity building by private extension services in proper sowing time, whereas $39.3 \%$ respondents had no capacity building in proper time of sowing by private extension services. Similarly, to establish a proper orchard, plant to plant distance, row to row distance and every other pre-requisite requirement should be in line to take optimum fruit in future. Orchard layout is very technical job and only experts in the said field can do it accordingly. Therefore, to train and build the capacity of farmers in this regard is also essential. The data revealed that $62.2 \%$ respondents confirmed the capacity building in orchard layout by public extension staff, while $28.9 \%$ respondents had no capacity building in orchard layout by public extension staff. Likewise, 34.1\% respondents had the capacity building in orchard layout by private extension services, while 58.9\% respondents reported no capacity building in orchard layout by private extension services.

\section{Paired t-test for capacity building by public and private extension services}

In order to find out the difference among public and private sector paired t-test was applied and results are presented in Table 4. Results depicts that there was highly significant $(p \leq 0.01)$ difference among public and private services regarding capacity building of farmers in terms of farm management, improve marketing skills, harvesting techniques, organic farming, integrated pest management, seed rate ratio and orchard layout. Furthermore, significant $(p \leq 0.05)$ difference was observed regarding selection of varieties and food processing whereas in the rest of variables non-significant difference was observed. The performance of private sector in capacity building was found better in most of the variables however in case of improve marketing skills, organic farming, orchard layout and integrated pest management the performance of the public sector extension system was better (Table 4, Figure 1). 
Table 4: Paired t-test of capacity building shared by public and private extension systems.

\begin{tabular}{|c|c|c|c|c|}
\hline $\begin{array}{l}\text { Capacity building by } \\
\text { public vs private sector }\end{array}$ & $\begin{array}{l}\text { Public } \\
\text { mean }\end{array}$ & $\begin{array}{l}\text { Private } \\
\text { mean }\end{array}$ & $\begin{array}{l}\text { Mean dif- } \\
\text { ference }\end{array}$ & ue \\
\hline Farm management & 2.77 & 3.39 & -.622 & $-4.11^{* *}$ \\
\hline Improve marketing skills & 3.40 & 2.67 & .730 & $5.01^{* *}$ \\
\hline Selection of varieties & 3.04 & 3.36 & -.315 & $-2.04^{*}$ \\
\hline Good selection of fertilizer & 3.01 & 3.23 & -.219 & $-1.40^{\text {ns }}$ \\
\hline Harvesting techniques & 2.79 & 3.39 & -.600 & $-3.80^{* *}$ \\
\hline Organic farming & 3.30 & 2.69 & .607 & $4.34^{* *}$ \\
\hline Food processing & 3.17 & 2.86 & .307 & $2.60^{*}$ \\
\hline $\begin{array}{l}\text { Integrated crop manage- } \\
\text { ment }\end{array}$ & 3.35 & 3.38 & .037 & $-0.20^{\mathrm{ns}}$ \\
\hline $\begin{array}{l}\text { Integrated pest manage- } \\
\text { ment }\end{array}$ & 3.55 & 2.68 & .870 & $6.19^{* *}$ \\
\hline Seed rate ratio & 2.88 & 3.35 & -.467 & $-3.06^{* *}$ \\
\hline Time of sowing & 2.86 & 3.15 & -.289 & $-1.88^{\mathrm{ns}}$ \\
\hline Drchard layout & 3.47 & 2.70 & .778 & $5.56^{* *}$ \\
\hline
\end{tabular}

Whereas * and *** Indicates significance at 5\% and 1\% level of probability, respectively.

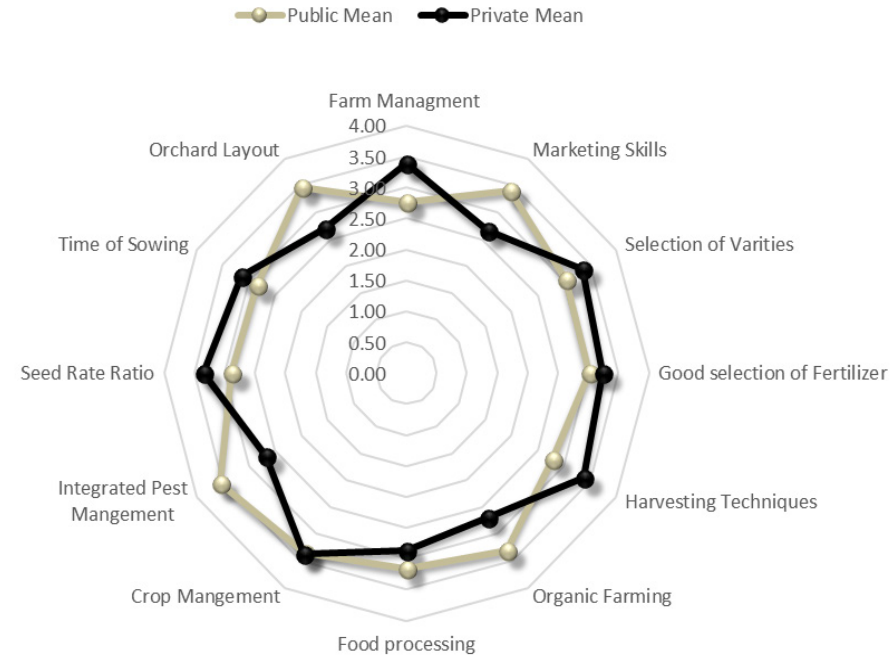

Figure 1: Capacity building by public and private extension services.

\section{Conclusions and Recommendations}

From the present study it is concluded that the capacity building of farmers by public or private extension sector was also quite better than the public sector. Private sector in capacity building was found better in most of the variables however in case of those variables which were not profit based for the public sector the performance of the public sector extension was better i.e. improving marketing skills, organic farming, orchard layout and integrated pest management. In the field of orchard layout and IPM, the better performance of the public extension sector might be due to the fact that they have their own nurseries and trained staff, while on the other hand private sector mostly focus on protection measures. Overall there was a big gap in the performance of the public sector extension and private sector extension in capacity building which might also be due to the fact that the private companies, NGOs etc. are quite in high numbers in comparison to the staff of the public sector thus they have high opportunity to reach maximum number of farmers and offered their services. It is suggested that both the public and private sector extension sector must work on joint venture basis and should holds joint extension activities for the betterment of farming community.

\section{Novelty Statement}

The current research highlighted the importance and performance of the public sector extension and private sector extension services for capacity building from farmers' perspective in Central plain Valley of Khyber Pakhtunkhwa, Pakistan.

\section{Authors Contribution}

Shahzad Malik: Principal author and Ph.D scholar, who collected the data, conducted the research and analysis.

Ayesha Khan: Major supervisor who conceived the idea of research, helped in data analysis and editing of the manuscript.

\section{Conflict of interest}

The authors have declared no conflict of interest.

\section{References}

Ahmad, D., 2012. Khyber Pakhtunkhwa State of the Environment. Peshawar: Environmental Protection Agency, Government of Khyber Pakhtunkhwa.

Ahmad, M., R. Rauf, M. Akram, I.A. Khan and A. Ali. 2007b. Adoption of farm machinery, chemical fertilizer and plant protection measures in NWFP province, Pakistan. Sarhad J. Agric., 23(4): 170-172.

Ajayi, O.J. and E.E. Gunn. 2009. The role of communication in dissemination of improved agricultural technology in Bosso Local government area of Niger, Nigeria. J. Agri. Ext., 13(1): 66-72. https://doi.org/10.4314/jae. v13i1.53879 
Ali, S., M. Ahmad and T. Ahmad. 2011a. Strengths and weaknesses of various information delivery methods used by private agricultural extension system in the Punjab, Pakistan. J. Agric. Res., 49(2): 15-21.

Ali, S., M. Ahmad, T. Ali, B. Shahbaz, G. A. Khan, M.Iftikhar and F. Nosheen. 2013. Role of private sector in promoting IPM practices among farming community in Punjab, Pakistan. J. Anim. Plant Sci., 23(5): 1473-1476.

Ali, S., M. Ahmad, T. Ali and I.Z. Muhamad. 2009. Analysis of competencies possessed by field staff of private agricultural extension system in Punjab. Pak. J. Agric. Res., 47(1): 101-106.

Ayinde, I.A., M.U. Agbonlahor, T.E. Mafimisebi and O.A. Adebayo. 2004. Assessment of the use of information communication technologies (ICT) on the economic performance of agro-based food industries in South-West Nigeria (No. 54373). Farm Management Association of Nigeria (FAMAN).

Bahalkani, N.A., 2013. Study on the diffusion and adoption of production practices of hybrid rice in Taluka Tangwani, District Kashmore, Sindh. M.Sc. Thesis, Agric. Ext., Sindh Agric. Univ., Tandojam Sindh, Pakistan.

Gordon, J. and K. Chadwick. 2007. Impact assessment of capacity building and training: assessment framework and two case studies. Aust. Cen. Int. Agric. Res., 44: 1-117.

Government of Pakistan, 2017-18. Pakistan economic survey, Ministry of Finance, Economic Advisor's Wing, Finance Division, Islamabad, Pakistan.

Heemskerk, W. and K. Davis. 2012. Pluralistic extension systems. In World Bank (ed.), agricultural innovation systems. An investment sourcebook. World Bank, Washington DC. pp. 194-203.

Iqbal, M. and K. Nawab. 2013. Farmers Field Schools and bitter gourd productivity: An empirical analysis of district Charsadda, Khyber Pakhtunkhwa-Pakistan. Sarhad J. Agric., 29(4): 35-78.

Kamal, T., 2013. Role of agricultural extension agents in enhancing tomato production in district Peshawar, Khyber Pakhtunkhwa-Pakistan. M.Sc. Thesis. Department of Agricultural Extension Education and Communication, The Univ. of Agri., Peshawar.

Khan,A.A.,2006. Strengthening education research extension linkages for effective agricultural extension services: Experience of Pakistan. In: V.P. Sharma. (ed.). Enhanc. Ext. Syst. Agric. APO, Tokyo, Japan. pp. 145-150.

Khan, F., 2015. Role of extension services on production of sugarcane in district Mardan and Charsadda: Khyber Pakhtunkhwa-Pakistan. Doctoral dissertation, Deppt. Agric. Ext. Educ. Comm., Univ. Agric. Peshawar, Pakistan. pp. 176-181.

Kumbhar, M.I., S.A. Sheikh, S. Mughal and M.J. Channa. 2012. Perception of the extension agents regarding information sources of sustainable agriculture in Sindh province of Pakistan. J. Basic App. Sci., (8): 334-338.

Khushk, A.M. and A. Memon. 2004. Increasing wheat yield. The daily DAWN. Economic and business Review, 5 April.

Kasely, D.J. and K. Kumar. 1989. The collection, analysis and use of monitoring and evaluation data. The World Bank, IFAD, FAO, London: John Hophkins Univ. Press.

Likert, R., 1932. A technique for the easurement of attitudes: Arch. Psychol., 22(140): 1-55.

Lodhi, T.E., M. Luqman and G.A. Khan. 2006. Perceived effectiveness of public sector extension under decentralized agricultural extension system in the Punjab, Pakistan. J. Agric. Soc. Sci., 2(3): 195-200.

Park, H.M., 2009. Comparing group means: T-tests and one-way ANOVA using STATA, SAS, $\mathrm{R}$ and SPSS. Working Paper. The University Information Techno-logy Services (UITS) Centre for Statistical and Mathematical Computing, Indiana University, USA.

Pretty, J., 2008. Agricultural sustainability concepts, principles and evidence. Philos. Trans. R. Soc. London B. Biol. Sci., 363(1491): 447-465. https://doi.org/10.1098/rstb.2007.2163

Sathish, H., 2015. Systems analysis of public and private agricultural extension service providers in karnataka (Doctoral dissertation).

Singh, A.K. and S. Narain. 2008. Effectiveness of public and private extension system in delivering services. Indian Res. J. Ext. Edu., 8(2-3): 29-31.

Umeh, O.J., D.N. Aghale and A. Anyim. 2018. Assessment of influence of extension teaching methods on the level of adoption of agricultural innovation in Akwa-Ibom State, Nigeria. Int. J. Adv. Res. Bot., 4(1): 1-6. https://doi. org/10.20431/2455-4316.0401001 
World Bank, 2010. Gender and governance in rural services: Insights from India, Ghana, and Ethiopia. Agriculture and rural development. Washington, DC, USA: The World Bank.

Zaman, S.B., W. Farooq, S. Majeed, H. Shah and A.
Majid. 2016. Assessment of agriculture service providers' training on water conservation technologies in pothwar region. Pak. J. Agric. Res., 29(1): 3-5. 